\title{
Corrigendum: Self-Perception of Changes in Routines in Adults and Older Adults Associated to Social Distancing Due to COVID-19-A Study in São Paulo, Brazil
}

\begin{abstract}
Adriana Machado-Lima, Angélica Castilho Alonso, Débora Gozzo, Gisele Garcia Zanca, Guilherme Carlos Brech, José Maria Montiel, Marta Ferreira Bastos*, Priscila Larcher Longo and Sandra Regina Mota-Ortiz
\end{abstract}

Postgraduate Program in Aging Sciences, São Judas Tadeu University, São Paulo, Brazil

Keywords: adults, aged, COVID-19, perception, social distance

\section{A Corrigendum on}

\section{OPEN ACCESS}

Edited and reviewed by: Michela Di Trani,

Sapienza University of Rome, Italy

*Correspondence:

Marta Ferreira Bastos marta.bastos@saojudas.br

Specialty section:

This article was submitted to Health Psychology, a section of the journal Frontiers in Psychology

Received: 23 March 2021 Accepted: 08 April 2021 Published: 19 May 2021

Citation:

Machado-Lima A, Alonso AC

Gozzo D, Zanca GG, Brech GC,

Montiel JM, Bastos MF, Longo PL and Mota-Ortiz SR (2021) Corrigendum:

Self-Perception of Changes in Routines in Adults and Older Adults Associated to Social Distancing Due to COVID-19-A Study in São Paulo, Brazil. Front. Psychol. 12:684729. doi: 10.3389/fpsyg.2021.684729
Self-Perception of Changes in Routines in Adults and Older Adults Associated to Social Distancing Due to COVID-19-A Study in São Paulo, Brazil

by Machado-Lima, A., Alonso, A. C., Gozzo, D., Zanca, G. G., Brech, G. C., Montiel, J. M., et al. (2021). Front. Psychol. 12:607559. doi: 10.3389/fpsyg.2021.607559

In the original article, there was an error. A citation was inserted incorrectly at the end of a paragraph.

A correction has been made to Discussion, Paragraph 6. The corrected paragraph is shown below.

With social distancing, people are modifying their social bonds, and this could result in a negative impact on the eating habits of the participants, especially the older adults (Allès et al., 2019). There is a correlation between social bonds and eating habits (Campos et al., 2000; Silveira et al., 2015). However, with stress, there may be changes in the quantity and the quality of the food consumed, a decrease in appetite (Petrowski et al., 2014; Reichenberger et al., 2018), as well as an increase in high caloric density food consumption. These alterations may lead to changes in glycemia, lipid profile, and consequently increased risk for the development of chronic diseases (Evers et al., 2010; Van Strien et al., 2012; Sinha, 2018). In the present study, adults reported lower frequency of fruit and vegetable intake and higher frequency of protein intake in comparison to older adults. Sidor and Rzymski (2020) have shown a decrease in fruit and vegetable consumption and a greater tendency to consume meat during social distancing among adults. Older adults usually eat less proteins, fruits, and vegetables, which may be related to the presence of chronic disease or with oral cavity alterations (Gaspareto et al., 2017; Ibge, 2019), reflecting on implications in muscle mass, such as sarcopenia and other adverse outcomes (do Nascimento Ferreira et al., 2017).

The authors apologize for this error and state that this does not change the scientific conclusions of the article in any way. The original article has been updated. 


\section{REFERENCES}

Allès, B., Samieri, C., Jutand, M.-A., Carmichael, P.-H., Shatenstein, B., Gaudreau, P., et al. (2019). Nutrient patterns, cognitive function, and decline in older persons: results from the three-city and NuAge studies. Nutrients 11:1808. doi: 10.3390/nu1 1081808

Campos, M. T. F. D. S., Monteiro, J. B. R., and Ornelas, A. P. R. D. C. (2000). Fatores que afetam o consumo alimentar e a nutrição do idoso. Rev. Nutr. 13, 157-165. doi: 10.1590/s1415-52732000000300002

do Nascimento Ferreira, M. P., Previdelli, ÁN., de Freitas, T. I., Marques, K. M., Goulart, R. M. M., and de Cássia de Aquino, R. (2017). Dietary patterns and associated factors among the elderly TT - Padrões dietéticos e fatores associados em idosos. Rev. Bras Geriatr. Gerontol. 20, 534-544.

Evers, C., Marijn Stok, F., and de Ridder, D. T. D. (2010). Feeding your feelings: emotion regulation strategies and emotional eating. Personal. Soc. Psychol. Bull. 36, 792-804. doi: 10.1177/0146167210371383

Gaspareto, N., Previdelli, ÁN., and de Cássia de Aquino, R. (2017). Factors associated with protein consumption in elderly. Rev. Nutr. 30, 805-816. doi: 10.1590/1678-98652017000600012

Ibge, A. (2019). PNAD Contínua 2018: Educação Avança no País, mas Desigualdades Raciais e por Região Persistem.. Available from: https:// agenciadenoticias.ibge.gov.br/agencia-sala-de-imprensa/2013-agencia-denoticias/releases/24857-pnad-continua-2018-educacao-avanca-no- pais-masdesigualdades-raciais-e-por-regiao-persistem (accessed August 29, 2020).

Petrowski, K., Wintermann, G. B., Joraschky, P., and Päßler, S. (2014). Chewing after stress: psychosocial stress influences chewing frequency, chewing efficacy, and appetite. Psychoneuroendocrinology 48, 64-76. doi: 10.1016/j.psyneuen.2014.06.008

Reichenberger, J., Kuppens, P., Liedlgruber, M., Wilhelm, F. H., Tiefengrabner, M., Ginzinger, S., et al. (2018). No haste, more taste: an EMA study of the effects of stress, negative and positive emotions on eating behavior. Biol. Psychol. 131, 54-62. doi: 10.1016/j.biopsycho.2016.09.002

Sidor, A., and Rzymski, P. (2020). Dietary choices and habits during COVID-19 lockdown: experience from poland. Nutrients 12, 1-13. doi: 10.4324/9781003121343-1

Silveira, E. A., Martins, B. B., de Abreu, L. R. S., Cardoso, C. K., and de Souza, K. C. (2015). Baixo consumo de frutas, verduras e legumes: fatores associados em idosos em capital no Centro-Oeste do Brasil. Cienc e Saude Coletiva 20, 3689-3699. doi: 10.1590/1413-812320152012.07352015

Sinha, R. (2018). Role of addiction and stress neurobiology on food intake and obesity. Biol. Psychol. 131, 5-13. doi: 10.1016/j.biopsycho.2017.05.001

Van Strien, T., Herman, C. P., Anschutz, D. J., Engels, R. C. M. E., and de Weerth, C. (2012). Moderation of distress-induced eating by emotional eating scores. Appetite 58, 277-284. doi: 10.1016/j.appet.2011.10.005

Copyright $\odot 2021$ Machado-Lima, Alonso, Gozzo, Zanca, Brech, Montiel, Bastos, Longo and Mota-Ortiz. This is an open-access article distributed under the terms of the Creative Commons Attribution License (CC BY). The use, distribution or reproduction in other forums is permitted, provided the original author(s) and the copyright owner(s) are credited and that the original publication in this journal is cited, in accordance with accepted academic practice. No use, distribution or reproduction is permitted which does not comply with these terms. 